\title{
TNFAIP3(A20) genetic alterations in AIDS-related lymphomas
}

\author{
Lisa Giulino ${ }^{1,2^{*}}$, Susan Matthew ${ }^{3}$, Wayne Tam³ ${ }^{3}$ Amy Chadburn ${ }^{4}$, Gianna Ballon ${ }^{3}$, Sharon Barouk ${ }^{3}$, \\ Giuseppina Antonicelli ${ }^{4}$, Lorenzo Leoncini ${ }^{4}$, Ethel Cesarman ${ }^{3}$ \\ From $12^{\text {th }}$ International Conference on Malignancies in AIDS and Other Acquired Immunodeficiencies \\ (ICMAOI) \\ Bethesda, MD, USA. 26-27 April, 2010
}

\section{Background}

AIDS-related lymphomas (ARLs), which include Burkitt lymphoma and diffuse large B cell lymphoma (DLBCL), are a heterogeneous group of lymphoproliferative disorders that occur in the setting of HIV-mediated immune suppression. A subset of cases are associated with EpsteinBarr virus (EBV) infection. EBV expresses latent viral oncoproteins that constitutively activate the transcription factor NF- $\kappa \mathrm{B}$, a potent inducer of genes involved in promoting $B$ cell survival and proliferation [1].

In immunocompetent individuals, lymphomas that are not associated with EBV can also display increased NF$\kappa \mathrm{B}$ activity, and recent reports have described mutations in regulators of NF- $\kappa \mathrm{B}$. One of the frequently mutated regulatory genes is TNFAIP3, which encodes A20, a ubiquitin modifying enzyme involved in the termination of NF- $\kappa \mathrm{B}$ signaling. Mutations resulting in the inactivation of A20 have been found in a significant proportion of marginal zone lymphomas [2], classical Hodgkin's lymphomas and primary mediastinal B cell lymphomas [3], and DLBCLs [4]. In ARL the role of NF- $\kappa$ B activation and the incidence of mutations in A20 have not been described.

\section{Materials and methods}

We evaluated archival formalin-fixed paraffin-embedded tissue samples of AIDS-related lymphoma for genetic alterations in A20. Tissue was collected through an international collaboration between Weill Cornell Medical College in New York, NY, and Siena University in Siena, Italy. A tissue microarray with 48 cases of ARL

\footnotetext{
*Correspondence: giulinol@mskcc.org

'Department of Pediatrics, New York Presbyterian Hospital - Cornell, New

York, NY, USA

Full list of author information is available at the end of the article
}

was prepared, and characterization of viral status and lymphoma subtype were determined by immunohistochemistry and in situ hybridization for Epstein-Barr encoded RNA (EBER). Fluorescent in situ hybridization (FISH) was used to evaluate for genomic deletions in A20, and translocations of cMYC, BCL-2, and BCL-6. Direct sequencing of the coding region of A20 was performed to evaluate for additional mutations.

\section{Results}

FISH was performed on 48 cases of ARL. Of 21 cases with successful hybridization loss of heterozygosity at the A20 locus was observed in 6 cases (28\%). Cases with A20 deletion included three diffuse large B cell lymphomas, two Burkitt lymphomas, and one Burkitt-like lymphoma. Two cases were positive for EBER but all were negative for latent membrane protein-1 (LMP-1). Partial sequencing of approximately $70 \%$ of the A20 coding regions in 23 cases did not reveal additional mutations.

\section{Conclusions}

A20 may represent a tumor suppressor gene in a subset of AIDS-related lymphomas. Inactivation of A20 may be an alternative mechanism of NF- $\kappa \mathrm{B}$ upregulation in the absence of LMP-1.

\section{Acknowledgements \\ This article has been published as part of Infectious Agents and Cancer Volume 5 Supplement 1, 2010: Proceedings of the $12^{\text {th }}$ International Conference on Malignancies in AIDS and Other Acquired Immunodeficiencies (ICMAOI). The full contents of the supplement are available online at http://www.biomedcentral.com/1750-9378/5?issue=S1}

\section{Author details}

${ }^{1}$ Department of Pediatrics, New York Presbyterian Hospital - Cornell, New York, NY, USA. ${ }^{2}$ Department of Pediatrics, Memorial Sloan-Kettering Cancer Center, New York, NY, USA. ${ }^{3}$ Department of Pathology, Weill Cornell Medical 
Published: 11 October 2010

\section{References}

1. Keller SA, Hernandez-Hopkins D, Vider J, Ponomarev V, Hyjek E,

Schattner EJ, Cesarman E: NF-kappaB is essential for the progression of KSHV- and EBV-infected lymphomas in vivo. Blood 2006,

107(8):3295-3302.

2. Novak U, Rinaldi A, Kwee I, Nandula SV, Rancoita PM, Compagno M, Cerri M, Rossi D, Murty W, Zucca E, et al: The NF-\{kappa\}B negative regulator TNFAIP3 (A20) is inactivated by somatic mutations and genomic deletions in marginal zone lymphomas. Blood 2009, 113(20):4918-4921.

3. Schmitz R, Hansmann ML, Bohle V, Martin-Subero Jl, Hartmann S, Mechtersheimer G, Klapper W, Vater I, Giefing M, Gesk S, et al: TNFAIP3 (A20) is a tumor suppressor gene in Hodgkin lymphoma and primary mediastinal B cell lymphoma. J Exp Med 2009, 206(5):981-989.

4. Compagno M, Lim WK, Grunn A, Nandula SV, Brahmachary M, Shen Q, Bertoni F, Ponzoni M, Scandurra M, Califano A, et al: Mutations of multiple genes cause deregulation of NF-kappaB in diffuse large B-cell lymphoma. Nature 2009, 459(7247):717-721.

doi:10.1186/1750-9378-5-S1-A82

Cite this article as: Giulino et al:: TNFAIP3(A20) genetic alterations in AIDS-related lymphomas. Infectious Agents and Cancer 2010 5(Suppl 1): A82.

\section{Submit your next manuscript to BioMed Central} and take full advantage of:

- Convenient online submission

- Thorough peer review

- No space constraints or color figure charges

- Immediate publication on acceptance

- Inclusion in PubMed, CAS, Scopus and Google Scholar

- Research which is freely available for redistribution

Submit your manuscript at www.biomedcentral.com/submit
C Biomed Central 